International Journal of Management Science and Business Administration

Volume 3, Issue 5, July 2017, Pages 30-37

DOI: 10.18775/ijmsba.1849-5664-5419.2014.35.1003

URL: http://dx.doi.org/10.18775/ijmsba.1849-5664-5419.2014.35.1003

\title{
Economic Growth and $\mathrm{CO}_{2}$ Emissions for OECD Countries
}

\author{
Hasan Hüseyin Yildirim \\ Lecturer, University of Balikesir, Balikesir, Turkey
}

\begin{abstract}
Following the 19th century Energy became an important and indispensable input for production and consumption activities all over the world. In the mean time, Energy has become a very determinant factor for growth for national economies. In this study, we aim to investigate the relationship between economic growth and $\mathrm{CO}_{2}$ emission for OECD countries. Panel data method and cointegration tests will be employed to analyze OECD member countries over the period 1960-2014. GDP per capita will be the Proxy for the economic growth and $\mathrm{CO}_{2}$ emissions (metric tons per capita) will be taken for $\mathrm{CO}_{2}$ emission on yearly basis.
\end{abstract}

Keywords: Economic Growth, $\mathrm{CO}_{2}$ Emission, Panel Data Analysis, Cointegration Test

\section{Introduction}

Energy plays a vital role in the process of economic growth and development of a nation. In the absence of sufficient energy industry, transport and social life are subject to fail(Chang and Carballo, 2011). Energy products constitute the largest cost item in the production processes in the modern economy. Being unable to meet energy demand due to population growth, industrialization and rising living standards can cause social, political and military conflicts.

Global primary energy consumption has poorly increased by just $0.9 \%$ in 2014, after a marked (slow down) deceleration over $2013(+2.0 \%)$ and well below the 10-year average of $2.1 \%$. Growth in 2014 slowed for every fuel other than nuclear power, which was also the only fuel to grow at an above-average rate. Growth was significantly below the 10-year average for Asia Pacific, Europe \& Eurasia, and South \& Central America. OECD consumption fell by $0.9 \%$, which was a larger fall than the recent historical average.

Table 1: World Primary Energy Consumption (2014)

\begin{tabular}{|l|c|c|c|c|c|c|c|c|}
\cline { 2 - 9 } \multicolumn{1}{c|}{} & \multicolumn{9}{c|}{ Primary Energy Consumption } \\
\cline { 2 - 10 } \multicolumn{1}{c|}{ Region } & Oil (Mt) & $\begin{array}{c}\text { Natural } \\
\text { Gas (Mtoe) }\end{array}$ & $\begin{array}{c}\text { Coal } \\
\text { (Mtoe) }\end{array}$ & $\begin{array}{c}\text { Nuclear } \\
\text { Energy } \\
\text { (Mtoe) }\end{array}$ & $\begin{array}{c}\text { Hydro- } \\
\text { Electricity } \\
\text { (Mtoe) }\end{array}$ & $\begin{array}{c}\text { Renew- } \\
\text { ables (Mtoe) }\end{array}$ & Total & Percent \\
\hline Total North America & 1024.4 & 866.3 & 488.9 & 216.1 & 153.5 & 73.6 & 2822.6 & 0.22 \\
\hline Total S.\& Cent. America & 326.5 & 153.1 & 31.6 & 4.7 & 155.4 & 21.5 & 692.8 & 0.05 \\
\hline Total Europe \& Eurasia & 858.9 & 908.7 & 476.5 & 266.1 & 195.7 & 124.4 & 2830.3 & 0.22 \\
\hline Total Middle East & 393.0 & 418.6 & 9.7 & 1.0 & 5.2 & 0.3 & 827.9 & 0.06 \\
\hline Total Africa & 179.4 & 108.1 & 98.6 & 3.6 & 27.5 & 2.9 & 420.1 & 0.03 \\
\hline Total Asia Pacific & 1428.9 & 610.7 & 2776.6 & 82.5 & 341.6 & 94.2 & 5334.6 & 0.41 \\
\hline Total World & $\mathbf{4 2 1 1 . 1}$ & $\mathbf{3 0 6 5 . 5}$ & $\mathbf{3 8 8 1 . 8}$ & $\mathbf{5 7 4 . 0}$ & $\mathbf{8 7 9 . 0}$ & $\mathbf{3 1 6 . 9}$ & $\mathbf{1 2 9 2 8 . 4}$ & \multicolumn{2}{|c|}{} \\
\hline Percent & $\mathbf{0 . 3 3}$ & $\mathbf{0 . 2 4}$ & $\mathbf{0 . 3 0}$ & $\mathbf{0 . 0 4}$ & $\mathbf{0 . 0 7}$ & $\mathbf{0 . 0 2}$ & &
\end{tabular}

Table 1 shows us the distribution of primary energy consumption in the year 2014 (BP, 2015). We can see that utilization of primary energy sources for the regions are proportions of $22 \%$ in North America, $5 \%$ in South \& Central 
America, 23\% in Europe \& Eurasia, 6\%, in the Middle East, 3\% in Africa, 41\% in Asia Pacific region. In 2014, oil which is the largest share of the world consumption of primary energy resources constituted $33 \%$ of whole consumption. Oil consumption is followed by coal, which is $30 \%$ of the world consumption. Natural gas is the third with $24 \%$ of primary energy consumption. $87 \%$ of world primary energy consumption is supplied by these three energy items, as a fossil source of energy. One of the most frequently-discussed global matters has been environmental destruction within contexts of global warming and climate change. The main reason for global warming is the very rapid increase in the ratio of gases that cause the greenhouse effect in the atmosphere. The increase in the emission of the carbon dioxide $(\mathrm{CO} 2)$ and methane gas in the atmosphere increases the temperature of the earth's surface. The main gas that causes the greenhouse effect is $\mathrm{CO} 2$, which is emitted into the atmosphere by the use of fossil fuels such as gasoline, coal, and natural gas(Yavuz, 2014:229). Using fossil resources in global energy consumption causes environmental expenditures. "Sustainability" and "sustainable development" have come into prominence in order to maintain the economic growth without increasing environmental expenditures (Ergün and Polat, 2015:117).

In the last 10 years in terms of energy demand in OECD countries at first place stands Turkey, according to the Ministry of Energy and Natural Resources Budget presentation in 2015. It is expected to reach 218 million TEP level of primary energy demand by 2023. İt is also expected that in 2023 primary energy demand in the coal goes from $27 \%$ to $37 \%$ of the share, the oil shares of $27 \%$ decrease to $26 \%$ and the natural gas shares decreases from $33 \%$ to $23 \%$, and it is also predicted for hydropower's share level will be $4 \%$, for renewable resources $6 \%$ and for the share of nuclear energy level $4 \%$.

The relationship between economic progress and environment is presented as a model with kuznets curve. According to the model, both the development and the growth of countries have 3 phases. At the first stage, countries enhance economic growth and consequently the energy consumption. Since it is more affordable, countries use fossil energy. The usage of fossil energy causes $\mathrm{CO} 2$ emission rise. At the second phase, countries have the economic growth in a particular way. The countries reach a certain economic growth level. However, the usage of $\mathrm{CO} 2$ has increased extremely. In the last phase, the countries desire to enhance the economic growth decreasing CO2 (Dinda, 20014:433; Stern, 2004:519).

The economic growth of the countries brings $\mathrm{CO} 2$ rise as well. Developing countries want to reduce the $\mathrm{CO} 2$ while maintaining economic growth in order to reach the developed country level. The point at which $\mathrm{CO} 2$ starts to decrease is called threshold point. Following the certain level of growth and the income rise, the measures to protect the environment are taken (Yandle vd., 2002:1-5). In this study, the relationship between OECD countries economic growth and the change in $\mathrm{CO} 2$ have been analyzed.

This study consists of five parts. The first part is the definition and the importance of $\mathrm{CO}_{2}$ with economic growth of OECD countries and the World. The second part is the literature review of economic growth and CO2 emissions. In the third part of the study, data sets and methods of the study in the methodology section are being described. In the fourth section of the study, empirical outputs are presented. The fifth chapter of this study illustrates concluded results.

\section{Literature Review}

There is a vast amount of research on the relationship between the level of income of a country and environmental pollution. Since Grossmann and Krueger (1991, 1993, 1995), who detected this inverted U-shaped relationship between gross domestic product and some pollution indicators at the beginning of 1990s, together with the serious increase of environmental destruction, the literature concerning this topic has been rapidly growing. The relationship between income and environmental pollution has been studied for groups of countries and also for individual countries (Yavuz, 2014:230). Although some of the applied studies support the environmental Kuznets curve hypothesis, some others do not. The models in which the relationship between environmental destruction and growth is searched for are generally criticized because of the omitted variable and the estimations are assumed to be biased. Richmond and Kaufmann (2006) included energy consumption within the model in order not to be exposed to the undesirable effects of the omitted variable and they determined a positive relationship. Soytas et al. (2007) searched for the Granger type causal relation between real income and $\mathrm{CO} 2$ emission. 
Table 2: Summary of Previous studies on the relationships between $\mathrm{CO}_{2}$ emission and economic growth

\begin{tabular}{|c|c|c|c|c|}
\hline Study & Country & Period & Methodology & Results (Causality) \\
\hline Ang (2007) & France & $1960-2000$ & $\begin{array}{l}\text { Johansen-Juselius, ARDL bounds } \\
\text { test, EKC, VECM }\end{array}$ & $\mathrm{EC} \rightarrow \mathrm{GDP}$ \\
\hline Halicioğlu (2008) & Turkey & $1960-2005$ & $\begin{array}{l}\text { ARDL bounds test, Johansen- } \\
\text { Juselius, VECM }\end{array}$ & $\begin{array}{l}\mathrm{CO}_{2} \leftarrow \rightarrow \mathrm{EC} \\
\mathrm{CO}_{2} \leftarrow \rightarrow \mathrm{GDP}\end{array}$ \\
\hline $\begin{array}{l}\text { Jalil and Mahmud } \\
\text { (2009) }\end{array}$ & China & 1975-2005 & ARDL bounds test, EKC, VECM & $\mathrm{GDP} \rightarrow \mathrm{CO}_{2}$ \\
\hline $\begin{array}{l}\text { Zhang and Cheng } \\
\text { (2009) }\end{array}$ & China & 1960-2007 & Toda-Yamamoto procedure & $\begin{array}{l}\mathrm{GDP} \rightarrow \mathrm{EC} \\
\mathrm{EC} \rightarrow \mathrm{CO}_{2}\end{array}$ \\
\hline $\begin{array}{l}\text { Lean and Smyth } \\
\text { (2010) }\end{array}$ & Five ASEAN countries & $1980-2006$ & $\begin{array}{l}\text { Johansen Fisher panel cointegration } \\
\text { EKC, panel VECM }\end{array}$ & $\mathrm{CO}_{2} \leftarrow \rightarrow \mathrm{GDP}$ \\
\hline Menegaki (2011) & 27 Europen countries & 1997-2007 & Panel cointegration test & $\mathrm{CO}_{2} \leftarrow \rightarrow \mathrm{GSYH}$ \\
\hline Arı and Zeren (2011) & $\begin{array}{l}\text { The Mediterranian } \\
\text { Countries }\end{array}$ & $2000-2005$ & Panel Data Model & $\mathrm{GDP} \rightarrow \mathrm{CO}_{2}$ \\
\hline
\end{tabular}

Table 2 summarizes some earlier relevant studies with their main features including methodology employed and main findings. In Table 2, from many studies, a certain part of the relationship between the $\mathrm{CO} 2$ and the economic growth is shown. There are differences in the results of these studies with regard to GDP, GDP per capita, pollution level and the usage of pollution level per person, the kind of pollution emission used, usage of different explanatory variable apart from the variable in hand, differences of theoretical models, the terms and the countries analyzed. These differences can cause variant results even at the analyses of the same countries.

\section{Methodology}

This study is aimed to investigate the relationship between economic growth and $\mathrm{CO}_{2}$ emission for OECD countries. Panel data method and cointegration tests will be employed to analyze OECD member countries over the period 19602014. GDP per capita will be the Proxy for the economic growth and $\mathrm{CO}_{2}$ emission (metric tons per capita) will be taken for $\mathrm{CO}_{2}$ emission on yearly basis.

\subsection{Data Set}

Data set used in this study includes the period 1962-2011 and analyses have been conducted by using eighteen EOCD countries and 51 observations on annually data basis. Closing data pertain to GDP per capita and $\mathrm{CO}_{2} \mathrm{Emissions}$ (metric tons per capita). Both data have been obtained from World Bank data base. Excel 2010 and E-Views 8.0 package programs have been used for processing the data and implementation of econometric analyses.

\subsection{Methods}

Panel data analyses embody information across both time and space. By using this approach we can bring to light the expected values and relationship between macroeconomic variables. Importantly, a panel keeps the same objects or entities and measures some quantity about them over time. Therefore we can put together observations for individuals, countries, firms and other entities for a specific period of time. (Tatoğlu, 2012: 2).

Economic data are often non-stationary or have means, variances, and covariances that change over time. A statistical analysis of a time series should be done whether it has a constant mean over time. The use of non-stationary data can lead to spurious regressions. If two variables are non-stationary, a regression of one on the other could have a high $\mathrm{R}^{2}$ even if the two are totally unrelated. So, if standard regression techniques are applied to non-stationary data, the end result could be a regression that looks good but fundamentally they are valueless. Such a model would be termed a spurious regression.

Recent literature suggests that panel-based unit root tests have higher power than unit root tests based on individual time series*.

\footnotetext{
*. Levin, Lin and Chu (2002), Breitung (2000), Im, Pesaran and Shin (2003), Fisher-type tests using ADF and PP tests (Maddala and Wu (1999) and Choi (2001)), and Hadri (2000).
} 
While these tests are commonly termed "panel unit root" tests, theoretically, they are simply multiple-series unit root tests that have been applied to panel data structures (where the presence of cross-sections generates "multiple series" out of a single series). These tests can be done for multiple series. In this study, Levin, Lin and Chuunit root tests and Fisher ADF and Fisher Philips and Perron panel unit root tests are employed.

Levin, Lin and Chu (2002) panel unit root test assumes that each unit has the same autoregressive parameter. In other words, Levin, Lin, and Chu propose a test which has an alternative hypothesis that the $\rho_{\mathrm{i}}$ are identical. Because $\rho_{\mathrm{i}}$ is fixed across $i$, this is one of the most complicated of the tests because the data from the different individuals need to be combined into a single final regression. Three models can be applied:

$$
\begin{array}{r}
\text { Model 1: } \Delta Y_{i t}=\rho Y_{i t-1}+u_{i t} \text { (1) } \\
\text { Model 2: } \Delta Y_{i t}=\alpha_{0 i}+\rho Y_{i t-1}+u_{i t} \text { (2) } \\
\text { Model 3: } \Delta Y_{i t}=\alpha_{0 i}+\alpha_{0 i} t+\rho Y_{i t-1}+u_{i t} \text { (3) }
\end{array}
$$

The Fisher-ADF and PP panel unit root tests allow for individual unit root processes so that $\rho_{i}$ may vary across crosssections. The tests are all characterized by the combining of individual unit root tests to derive a panel-specific result. Panel unit root tests are similar, but not identical, to unit root tests carried out on a single series. Fisher tests use unit root tests for each entity and then p-values obtained from these tests constitute the basis for executing the whole test. On the hand, Fisher ADF and Fisher Philips-Perron tests are executed for each entity.

Levin, Lin, and Chu tests assume that there is a common unit root process so that $\rho_{\mathrm{i}}$ is identical across cross-sections. Under the null hypothesis, there is a unit root, while under the alternative, there is no unit root. The LLC method requires a specification of the number of lags used in each cross-section ADF regression. On top of it, the exogenous variables used in the test equations must be specified. There is an option to include no exogenous regressors, or to include individual constant terms (fixed effects), or to employ individual constants and trends. An alternative approach to panel unit root tests uses Fisher's results to derive tests that combine the p-values from individual unit root tests. This idea has been proposed by Maddala and $\mathrm{Wu}$, and by Choi. The exogenous variables for the test equations and the number of lags used in each cross-section ADF regression must be specified for Fisher tests.Since Fisher tests allow us to use unbalanced panel data they are more flexible.

Once you have been able to classify your variables as stationary we are in a position to sort out long-run and short-run effects in your model and to set up a model where statistical inference will be meaningful. The extensive interest in and the availability of panel data has led to an emphasis on extending various statistical tests to panel data. Recent literature has focused on tests of cointegration in a panel setting. (Pedroni 1999, Pedroni 2004, Kao 1999 and a Fisher-type test using an underlying Johansen methodology Maddala and Wu 1999). Pedroni (1999) extended his panel cointegration testing procedure for the models, where there are more than one independent variable in the regression equation.

Basically, it employs four-panel statistics and three group panel statistics to test the null hypothesis of no cointegration against the alternative hypothesis of cointegration. In the case of panel statistics, the first-order autoregressive term is assumed to be the same across all the cross sections, while in the case of group panel statistics the parameter is allowed to vary over the cross sections. If the null is rejected in the panel case, then the variables of the production (labor productivity) function are cointegrated for all the sectors. On the other hand, if the null is rejected in the group panel case, then cointegration among the relevant variables exists for at least one of the sectors.

The can be summarized as below:

$$
y_{i t}=\alpha_{i}+\delta_{i} t+\beta_{1 i} X_{1 i t}+\beta_{2 i} X_{2 i t}+\ldots+\beta_{M i} X_{M i t}+\varepsilon_{i t}
$$

The Kao test follows the same basic approach as the Pedroni tests but specifies cross-section specific intercepts and homogeneous coefficients on the first-stage regressors.Kao (1999) Panel Cointegration tests are based on DF (Dickey Fuller) and $\mathrm{ADF}$ (Augmented Dickey Fuller) tests. Under the null hypothesis, there is no cointegration $\left(H_{0}: \rho=1\right)$.

$$
y_{i t}=X_{i t} \beta+z_{i t} \gamma+\varepsilon_{i t}(\mathbf{5})
$$

Based on the results obtained from cointegration analyses for panel data, panel causality tests are employed. In order to perform a causality test, a Vector Error Correction Model can be predicted by using VAR. 


\section{Empirical Results}

In this analysis, GDP per capita and $\mathrm{CO}_{2}$ Emissions (metric tons per capita) data have been used for 18 OECD member countries (Austria, Belgium, Canada, Denmark, France, Greece, Iceland, Ireland, Luxembourg, Netherlands, Norway, Portugal, Spain, Sweden, Turkey, United Kingdom, United States and Italy) and all data have been obtained from World Bank data base.

Panel data analysis has been employed to investigate whether there is a relationship between GDP per capita and $\mathrm{CO}_{2}$ Emission in the countries mentioned above. Levin, Lin\&Chu, ADF, PP (1979) panel unit root tests have been conducted for the set covariables to see whether they are stationary or not.

Table 3: Results of Unit Root Test (Level Values)

\begin{tabular}{|l|l|c|c|}
\hline \multirow{2}{*}{ Unit Root Test Type } & \multicolumn{1}{|c|}{ Variables } & $\begin{array}{c}\text { GDP per capita } \\
\text { (current US\$) }\end{array}$ & $\begin{array}{c}\text { CO2 Emissions } \\
\text { (metric tons per } \\
\text { capita) }\end{array}$ \\
\hline \multirow{3}{*}{ Levin, Lin \&Chu } & Include in Test Equation & 10.1742 & -4.2412 \\
& Individual intercept & $(1.000)$ & $(0.000)$ \\
\cline { 2 - 4 } & Individual intercept and trend & $(0.999)$ & 0.6873 \\
\hline \multirow{3}{*}{ ADF- Fisher Chi- } & Individual intercept & 0.4112 & $(0.7541)$ \\
\cline { 2 - 4 } square & Individual intercept and trend & $(1.000)$ & 65.427 \\
& & 32.1296 & $(0.001)$ \\
\hline \multirow{3}{*}{ PP-Fisher Chi-square } & Individual intercept & $(0.428)$ & $(0.183)$ \\
\cline { 2 - 4 } & Individual intercept and trend & $(1.000)$ & 63.807 \\
& & 15.7102 & $(0.002)$ \\
\hline
\end{tabular}

In Table 3 above stationarity level results for two variables are shown. Under these hypotheses,

$\mathrm{H}_{0}$ : Variable is non-stationary. There is unit root.

$\mathrm{H}_{1}$ : Variable is stationary. There is no unit root.

the null hypothesis cannot be rejected for GDP per capita with constant, with constant and trend at $1 \%$ significance level. Moreover, for the $\mathrm{CO}_{2}$ Emissions (metric tons per capita)variable the null hypothesis cannot be rejected with constant and trend at $1 \%$ significance level. Since they are not stationary, stationarity process has to be employed.

Table 4: Results of UnitRoot Test (First Difference)

\begin{tabular}{|l|l|c|c|}
\hline \multirow{3}{*}{ Unit Root Test Type } & Variables & $\begin{array}{c}\text { GDP per capita } \\
\text { (current US\$) }\end{array}$ & $\begin{array}{c}\text { CO2 Emissions } \\
\text { (metric tons per } \\
\text { capita) }\end{array}$ \\
\hline \multirow{4}{*}{ Levin, Lin \&Chu } & Include in Test Equation & -18.050 & -22.829 \\
& Individual intercept & $(0.000)$ & $(0.000)$ \\
\cline { 2 - 4 } & Individual intercept and trend & -11.321 & -23.760 \\
& & $(0.000)$ & $(0.000)$ \\
\hline \multirow{3}{*}{ ADF- Fisher Chi- } & Individual intercept & 319.88 & 481.91 \\
\cline { 2 - 4 } & Individual intercept and trend & $(0.000)$ & $(0.000)$ \\
\hline \multirow{3}{*}{ PP-Fisher Chi-square } & Individual intercept & 288.60 & 475.46 \\
\cline { 2 - 4 } & Individual intercept and trend & $(0.000)$ & $(0.000)$ \\
\cline { 2 - 4 } & & 309.50 & 520.371 \\
& & $(0.000)$ & $(0.000)$ \\
\hline
\end{tabular}


When we take the first difference, both variables become stationary at $1 \%$ significance level as shown in Table 4 .

At this stage of the study, a cointegration test has been conducted to see the relationship between two variables. The results are shown in Table 5 below:

Table 5: Panel Cointegration Test Results

\begin{tabular}{|c|c|c|c|c|c|}
\hline \multirow[t]{2}{*}{ Test Type } & \multirow[t]{2}{*}{ Test Statistics } & \multicolumn{2}{|c|}{$\begin{array}{c}\text { GDP per capita Dependent } \\
\text { Variable }\end{array}$} & \multicolumn{2}{|c|}{$\begin{array}{c}\mathrm{CO}_{2} \text { Emissions } \\
\text { (metric tons per } \\
\text { capita)Dependent } \\
\text { Variable }\end{array}$} \\
\hline & & Statistic & Prob. & Statistic & Prob. \\
\hline \multirow{7}{*}{$\begin{array}{l}\text { Pedroni (Engle- } \\
\text { GrangerBased) }\end{array}$} & Panel v- Statistic & -0.7859 & 0.7475 & 3.7616 & 0.0001 \\
\hline & Panel rho- Statistic & -20.1929 & 0.0000 & -28.093 & 0.000 \\
\hline & Panel PP- Statistic & -15.3938 & 0.0000 & -21.779 & 0.000 \\
\hline & Panel ADF- Statistic & -15.9659 & 0.0000 & -21.678 & 0.000 \\
\hline & Grup rho- Statistic & -15.899 & 0.0000 & -29.605 & 0.000 \\
\hline & Grup PP-Statistic & -15.6967 & 0.0000 & -25.748 & 0.000 \\
\hline & Grup ADF- Statistic & -15.7651 & 0.0000 & -23.913 & 0.000 \\
\hline $\begin{array}{l}\text { Kao(Engle- } \\
\text { GrangerBased) }\end{array}$ & $\mathrm{ADF}$ & 4.5956 & 0.000 & -4.2705 & 0.000 \\
\hline
\end{tabular}

Under the null and alternative hypotheses,

$\mathrm{H}_{0}$ : There is no cointegration

$\mathrm{H}_{1}$ : There is cointegration

Pedroni test statistics confirms with the majority that the cointegration relationship exists. (6 out of 7 test statistics). Kao cointegration test statistics also confirm the same results at $5 \%$ significance level. In other words, the analysis affirms that first difference of GDP per capita in OECD countries and first difference of $\mathrm{CO}_{2}$ emissions (metric tons per capita) are cointegrated in the long run and they move together. Granger causality test results are shown below in Table 6.

Tablo 6: Granger Causality- Block Exogeneity Wald Test Results

\begin{tabular}{|c|c|c|c|c|c|c|}
\hline \multirow[b]{3}{*}{ Models } & Dependent & Independent & Chi-Square & Df & Prob. & Direction \\
\hline & $\begin{array}{l}\text { First Difference of } \\
\text { GDP per capita } \\
\text { (current US\$) }\end{array}$ & $\begin{array}{c}\text { First Difference of } \\
\mathrm{CO}_{2} \text { Emissions } \\
\text { (metric tons per capita) }\end{array}$ & 0.4869 & 2 & 0.7839 & $\begin{array}{c}\text { No } \\
\text { direction }\end{array}$ \\
\hline & $\begin{array}{c}\text { First Difference of } \\
\mathrm{CO}_{2} \text { Emissions } \\
\text { (metric tons per capita }\end{array}$ & $\begin{array}{l}\text { First Difference of } \\
\text { GDP per capita } \\
\text { (current US\$) }\end{array}$ & 21.1396 & 2 & 0.0000 & $\begin{array}{l}\text { Unidirecti } \\
\text { on }\end{array}$ \\
\hline
\end{tabular}

When we examine the results we conclude that there is a one direction relation. GDP per capita causes $\mathrm{CO}_{2}$ emissions. But $\mathrm{CO}_{2}$ emissions don't cause GDP per capita. According to the obtained results, it can be said that $\mathrm{CO}_{2}$ emissions have causality relationship in the direction of GDP, Also GDP has one-way causality relationship in the direction of $\mathrm{CO}_{2}$ emissions.

\section{Conclusion}

In this study, the relationship between the variables using the data of GDP per capita for economic growth and the $\mathrm{CO}_{2}$ emissions (metric tons per capita) for $\mathrm{CO}_{2}$ emission from 1961 to 2011 in eighteen OECD countries have been analyzed. Therefore, the stability of variables has been examined first. Afterward, variables have been examined to find out whether there is a cointegration among the variables or not. In the last step, granger causality test has been applied to the variables in order to determine the direction of the effect.

Short and long-term causality relationships among the variables have been detected as a result of granger cointegration. The simplex direction of the relationship has become evident thanks to granger causality test results. The relationship is 
from GDP per capita to $\mathrm{CO}_{2}$ emissions (metric tons per capita). According to this result, the growth in Turkey increases $\mathrm{CO}_{2}$ as in most developing countries. Developing countries use more fossil fuel for their energy consumption in order to achieve their economic growth. The energy sources in OECD countries consist of mainly fossil fuel. For this reason, economic growth brings forth the increase in energy consumption and consequently increases $\mathrm{CO}_{2}$ emission. The increase in economic growth for OECD countries, some of the developing countries, is substantial. However, it should not increase the $\mathrm{CO}_{2}$ while maintaining its economic growth since $\mathrm{CO}_{2}$ emission leads to environmental issues. Considering the environment fact in maintaining economic development for countries, sustainable development concept will be achieved if we appreciate the politics for the renewable energy, which is one of the cleanest energy sources.

\section{References}

- Ang, J.B., 2007, “CO2 emissions, energy consumption and output in France”, Energy Policy 35, 4772-4778. Crossref

- Ar1, A. and Zeren, F. (2011). CO2 Emission and Economic Growth: A Panel Data Analysis: University of Celal Bayar Bussiness and Economics Faculty Journal, 18(2), 37-47.

- BP, 2015, Statistical Review of World Energy June 2015, https://www.bp.com/content/dam/bp/pdf/energyeconomics/statistical-review-2015/bpstatistical-review-of-world energy-2015-full report.pdf

- Breitung, J. 2000, The local power of some unit root tests for panel data, in: B.Baltagi (ed.), Nonstationary Panels, Panel Cointegration, and Dynamic Panels, Advances in Econometrics, Vol. 15, JAI: Amsterdam, 161-178. Crossref

- Chang, C. C. and Carballo, C. F. S. (2011). Energy conservation and sustainable economic growth: The case of Latin America and the Caribbean. Energy Policy,39(7), 4215-4221. Crossref

- Choi, I., 2001, Unit root tests for panel data. Journal of international money and Finance, 20(2), 249-272. Crossref

- Dickey, D. A. and Fuller, W. A., 1979, "Distribution of the estimators for autoregressive time series with a unit root", Journal of the American statistical association, 74(366a), 427-431. Crossref

- Dinda, S., 2004, "Environmental Kuznets Curve Hypothesis: A Survey”, Ecological Economics, 49, pp. 431 -455. Crossref

- Ergün, S. and Polat, M., 2015, “OECD Ülkelerin de $\mathrm{CO}_{2}$ Emisyonu, Elektrik Tüketimi ve Büyüme İlişkisi”, Erciyes Üniversitesi, İktisadi ve İdari Bilimler Fakültesi Dergisi, Sayı:45, Ocak-Haziran, 2015, s.115-141

- Grossmann, G. M. and Krueger, A. B. 1991, "Environmental impact of a North American free trade agreement", NBER Working Paper 3914.

- Grossmann, G. M. and Krueger, A. B. 1993, "Environmental impact of a North American free trade agreement. In: The Mexico-US Free Trade Agreement", Garber, P. (Ed.). Cambridge, MA: MIT Press, pp. 13-56.

- Grossmann, G. M. and Krueger, A. B. 1995, "Economic growth and the environment", Q. J. Econ. 110:353-377. Crossref

- Hadri, K., 2000, Testing for stationarity in heterogeneous panel data. The Econometrics Journal, 3(2), 148-161. Crossref

- Halicioglu, F., 2009, “An econometric study of CO2 emissions, energy consumption, income and foreign trade in Turkey”, Energy Policy37, 1156-1164. Crossref

- Im, K. S., Pesaran, M. H. and Shin, Y. 2003, Testing for unit roots in heterogeneous panels. Journal of econometrics, 115(1), 53-74. Crossref

- Jalil, A. and Mahmud, S.F., 2009, "Environment Kuznets curve for CO2 emissions: a cointegration analysis for China", Energy Policy37, 5167-5172. $\underline{\text { Crossref }}$

- Kao, C. (1999). Spurious regression and residual-based tests for cointegration in panel data. Journal of econometrics, 90(1), 1-44. Crossref

- Lean, H. H. and Smyth, R., 2010, “CO2 emissions, electricity consumption and output in ASEAN”, Applied Energy 87, 1858-1864. Crossref

- Levin, A., Lin, C. F. and Chu, C. S. J. 2002, Unit root tests in panel data: asymptotic and finite-sample properties. Journal of econometrics, 108(1), 1-24. Crossref

- Maddala, G. S. and Wu, S. 1999, A comparative study of unit root tests with panel data and a new simple test. Oxford Bulletin of Economics and statistics, 61(S1), 631-652. Crossref

- Menegaki, A. N., 2011, "Growth and renewable energy in Europe: A random effect model with evidence for neutrality hypothesis" Energy Economics, 33(2), 257-263. Crossref 
- Richmond, A. K. and Kaufmann, R. K., 2006, "Is there a turning point in the relationship between income and energy use and/or carbon emissions", Ecol. Econ. 56:176-189. $\underline{\text { Crossref }}$

- Soytaş, U., Sarı, R., and Ewing, B. T., 2007, "Energy consumption, income, and carbon emissions in the United States", Ecol. Econ. 62:482-489. Crossref

- Stern, D., 2004, “Environmental Kuznets Curve”, Encyclopedia of Energy, 2, pp. 517-525. Crossref

- Tatoğlu, F. Y., "Panel veri ekonometris: stata uygulamalı". Beta Basım Yayın, 2012.

- Yandle, B., Maya, V., Madhusudan, B., 2002, “The Environmental Kuznets Curve”, Perc Research Study 02-1, pp. 1-24

- Yavuz, N. Çil, 2014, “CO2 Emission, Energy Consumption, and Economic Growth for Turkey: Evidence from a Cointegration Test With a Structural Break”, Energy Sources, Part B: Economics, Planning, and Policy, 9:3, 229 235, DOI: 10.1080/15567249.2011.567222. $\underline{\text { Crossref }}$

- Zhang, X.P. and Cheng, X.M., 2009, "Energy consumption, carbon emissions, and economic growth in China", Ecological Economics 68, 2706-2712. Crossref 